Josephath Jeyabal Maria Praveena ${ }^{1 *}$, Jeyaraj Angelin Clara ${ }^{1}$, Susai Santhammal Rajendran ${ }^{1}$, Antony John Amalraj ${ }^{2}$

${ }^{1} P G$ and Research Department of Chemistry, Corrosion Research Centre St. Antony's College of Arts and Sciences for Women Thamaraipady, Tamil Nadu, India, ${ }^{2} P G$ and Research Department of Chemistry, Periyar EVR Government College, Trichy, Tamil Nadu, Inida
Scientific paper

ISSN 0351-9465, E-ISSN 2466-2585

UDC: $665.7 .038 .5: 669.141 .24: 535.361$

https://doi.org/10.5937/zasmat2104277P

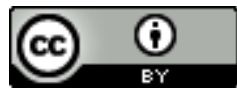

Zastita Materijala 62 (4)

$277-290(2021)$

\title{
Inhibition of corrosion of mild steel in well water by an aqueous extract of soapnut (Sapindus Trifoliatus)
}

\begin{abstract}
Inhibition efficiency of an aqueous extract of soapnut (Sapindus Trifoliatus) and $\mathrm{Zn}^{2+}$ in controlling corrosion of mild steel in well water at room temperature has been evaluated by using weight loss method, polarization study and AC impedance spectra. Dynamic light scattering and Vickers hardness have also been employed. Weight loss method reveals that the formulation consisting of $10 \mathrm{ml}$ soapnut extract and $50 \mathrm{ppm} \mathrm{Zn}^{2+}$ has $97 \%$ inhibition efficiency in controlling corrosion of mild steel immersed in well water. Synergism parameters suggest that a synergistic effect exists between soapnut extract and $\mathrm{Zn}^{2+}$. Adsorption isotherm of metal surface obeys Langmuir adsorption isotherm. Polarization study reveals that the inhibitor system functions as anodic type of inhibitor. AC impedance spectra confirm the protective film formed on the metal surface. Dynamic light scattering (DLS) study reveals surface is in nano meter scale. The Vickers hardness of metal surface was increases in inhibitor system.
\end{abstract}

Keywords: Sapindus Trifoliatus, corrosion inhibitor, mild steel, well water, dynamic light scattering, Vickers hardness.

\section{INTRODUCTION}

Mild steel (also known as plain carbon steel) is a widely used material in the fabrication of heating and cooling water system in many industries [1-3]. Corrosion is nothing but the deterioration of material on exposure to corrosive environments like moisture or other chemicals. Ultimately it leads to the failure of that material. Corrosion is a problem that can never be avoided but can be controlled to a greater extent. Due to this destructive phenomenon, there have been various accidents reported. Therefore, preventing corrosion has been a very important economical need [4-6]. Researchers have focused primarily on plantderived corrosion inhibitors due to their low cost and eco-friendly properties. The plant extracts such as Ervatamia divaricate [7], Chrysanthemum Indicumflower [8], Commelina benghalensisleaves

${ }^{*}$ Corresponding author: J. J. M. Praveena

E-mail: Praveenaregan@gmail.com

Paper received: 18. 07. 2021.

Paper corrected: 24. 08. 2021.

Paper accepted: 05. 09. 2021.

Paper is available on the website: www.idk.org.rs/journal
[9], Acanthus montanus leaves [10], Lawsonia Inermis L [11], Diospyros kaki (Persimmon) leaves [12], Mentha pulegium [13], Ambrosia maritima [14], Solanam Xanthocarpum Leaves [15] have been used as corrosion inhibitors.

The present research is focused on the effect of the aqueous extract of Sapindustrifoliatus as a corrosion inhibitor for mild steel corrosion in well water. Soapnut (Sapindustrifoliatus) (Figure 1) belongs to the family Sapindaceae. The plant is widely used in cosmetic preparation like shampoos and cleansers. Saponins are used for their effects on ammonia emissions in animal feeding $[16,17]$. Main active ingredient components of soapnut (Sapindus trifoliatus) is saponin (78.1\%) (Figure 2).

The present study is undertaken:

- To evaluate the corrosion resistance of mild steel in well water, in presence of an green corrosion inhibitor soapnut extract (sapindus trifoliatus).

- To determine inhibition efficiency, synergism parameter and Langmuir adsorption isotherm from data derived from weight loss method. 
- To develop Eco-friendly inhibitor system using readily available extract of plant sand Zinc for corrosion inhibition of mild steel in well water.

- To study the nature of process of corrosion inhibition and determine the type of inhibition whether anodic or cathodic or mixed using potentiodynamic polarization and Impedance studies.

- To examine the particle size Particle/molecular size, Size distribution, Relaxations in complex fluids by DLS method.

- To examine the hardness of metal surface by Vickers Hardness measurement.

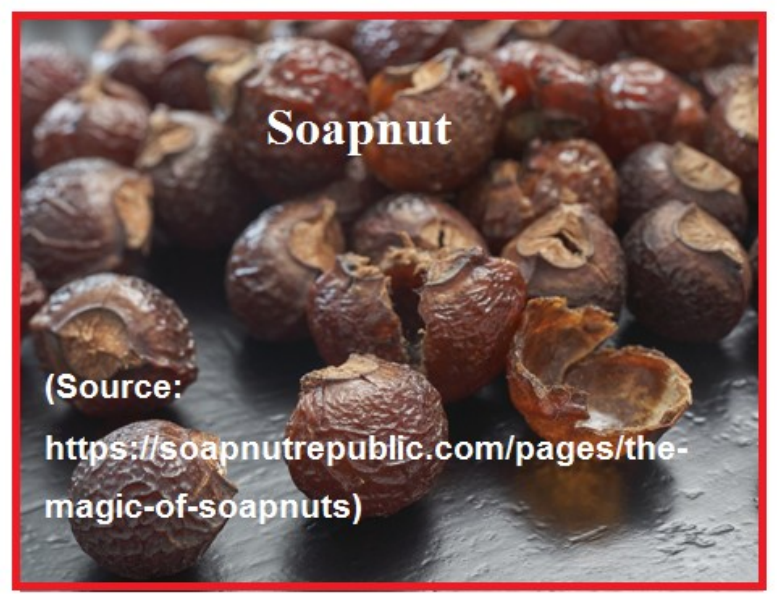

Figure1. Appearance of soapnut

Slika 1. Izgled sapunskog oraha

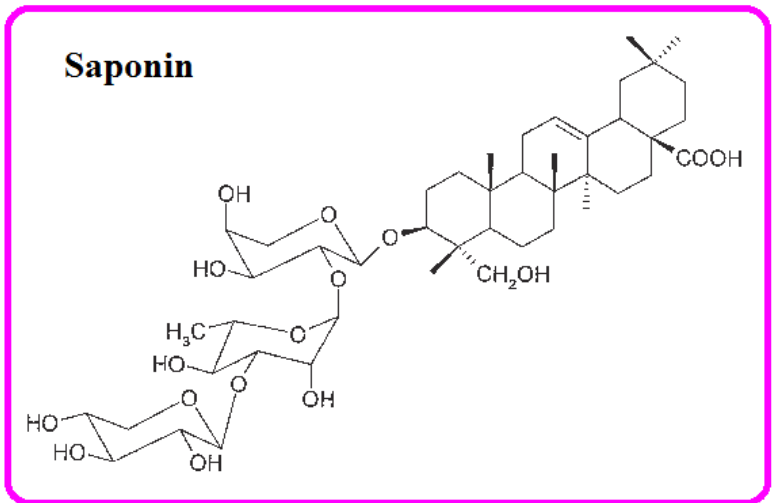

Figure 2. Structure of saponin

Slika 2. Struktura saponina

\section{Saponins}

Saponins are glucosides with foaming characteristics. Saponins consist of a polycyclic aglycones attached to one or more sugar side chains. The aglycone part, which is also called sapogenin, is either steroid (C27) or a triterpene (C30). The foaming ability of saponins is caused by the combination of a hydrophobic (fat-soluble) sapogenin and a hydrophilic (water-soluble) sugar part. Saponins have a bitter taste. Some saponins are toxic and are known as sapotoxin. Soapnut contains $78.1 \%$ saponins.

\section{MATERIALS AND METHODS}

\section{Preparation of inhibitor}

$10 \mathrm{~g}$ of soapnut fruit pulp was shade dried, weighed and boiled with double distilled water. The extract was filtered to remove suspended impurities and made up to $100 \mathrm{ml}$. The soapnut (SN) extract used as corrosion inhibitor in the present study.

\section{Preparation of mild steel (MS)}

Mild steel (iron containing a small percentage of carbon, strong and tough but not readily tempered), also known as plain-carbon steel and low-carbon steel, is now the most common form of steel acceptable for many applications. Mild steel is malleable and ductile. Mild steel has a relatively low tensile strength, but it is cheap and easy to form; surface hardness can be increased through carburizing. Composition of mild steel is given in Table1. This mild steel has been used in making hull plates.

Mild steel specimens of dimension $1 \mathrm{~cm} \times 4 \mathrm{~cm}$ $x 0.2 \mathrm{~cm}$ were used in weight loss method. In electrochemical studies, the exposed area of mild steel was $1 \mathrm{~cm}^{2}$. The mild steel specimens were cleaned with different grade emery papers and degreased with acetone.

\section{Well water}

The physico-chemical parameters of well water are given in Table 2.

Table 2. Physico-chemical parameters of well water

Tabela 2. Fizičko-hemijski parametri bunarske vode

\begin{tabular}{|c|c|}
\hline Parameters & Value \\
\hline $\mathrm{pH}$ & 8.38 \\
\hline Conductivity & $1770 \mu \Omega^{-1} \mathrm{~cm}^{-1}$ \\
\hline Chloride & $665 \mathrm{ppm}$ \\
\hline Sulphate & $214 \mathrm{ppm}$ \\
\hline TDS & $1100 \mathrm{ppm}$ \\
\hline Total hardness & $402 \mathrm{ppm}$ \\
\hline Total Alkalinity & $390 \mathrm{ppm}$ \\
\hline Magnesium & $83 \mathrm{ppm}$ \\
\hline Potassium & $55 \mathrm{ppm}$ \\
\hline Sodium & $172 \mathrm{ppm}$ \\
\hline Calcium & $88 \mathrm{ppm}$ \\
\hline
\end{tabular}


Table1. Composition of MS

Tabela 1. Sastav MS

\begin{tabular}{|c|c|c|c|c|c|c|}
\hline Name & unit & Average & Abs.Std.Dev & Ref.Std.Dev & $\mathbf{1}$ & 2 \\
\hline $\mathrm{C}$ & $\%$ & 0.101 & 0.0014 & 1.4 & 0.102 & 0.1 \\
\hline $\mathrm{Si}$ & $\%$ & 0.055 & 0.0021 & 3.89 & 0.053 & 0.056 \\
\hline $\mathrm{Mn}$ & $\%$ & 1.629 & 0.0057 & 0.35 & 1.633 & 1.625 \\
\hline $\mathrm{P}$ & $\%$ & 0.0087 & 0.0003 & 3.25 & 0.0085 & 0.0089 \\
\hline $\mathrm{S}$ & $\%$ & 0.0028 & 0.0003 & 10.1 & 0.0026 & 0.003 \\
\hline $\mathrm{Cr}$ & $\%$ & 0.036 & 0.0014 & 3.93 & 0.037 & 0.035 \\
\hline $\mathrm{Mo}$ & $\%$ & 0.0086 & 0.00007 & 0.83 & 0.0086 & 0.0085 \\
\hline $\mathrm{Ni}$ & $\%$ & 0.033 & 0.0007 & 2.18 & 0.033 & 0.32 \\
\hline $\mathrm{Cu}$ & $\%$ & 0.0063 & 0.00007 & 1.13 & 0.0062 & 0.0063 \\
\hline $\mathrm{Al}$ & $\%$ & 0.044 & 0.0014 & 3.21 & 0.043 & 0.045 \\
\hline $\mathrm{As}$ & $\%$ & 0.0011 & 0 & 0 & 0.0011 & 0.011 \\
\hline $\mathrm{B}$ & $\%$ & 0.0027 & 0.0005 & 18.68 & $<0.00010$ & $<0.00010$ \\
\hline $\mathrm{Bi}$ & $\%$ & $<0.00010$ & 0.00002 & 84.85 & $<0.0025$ & 0.003 \\
\hline $\mathrm{Ce}$ & $\%$ & 0.0032 & 0.0013 & 42.65 & 0.0041 & 0.0022 \\
\hline $\mathrm{Co}$ & $\%$ & 0.011 & 0 & 0 & 0.011 & 0.011 \\
\hline $\mathrm{Mg}$ & $\%$ & 0.0003 & 0 & 0 & 0.0003 & 0.0003 \\
\hline $\mathrm{Nb}$ & $\%$ & 0.03 & 0.0007 & 2.4 & 0.029 & 0.03 \\
\hline $\mathrm{Pb}$ & $\%$ & 0.0081 & 0.0013 & 15.71 & 0.0072 & 0.009 \\
\hline $\mathrm{Sb}$ & $\%$ & 0.004 & 0.0004 & 8.95 & 0.0037 & 0.0042 \\
\hline $\mathrm{Sn}$ & $\%$ & 0.0034 & 0 & 0 & 0.0034 & 0.0034 \\
\hline $\mathrm{Ta}$ & $\%$ & 0.03 & 0.0071 & 23.57 & 0.025 & 0.035 \\
\hline $\mathrm{La}$ & $\%$ & 0.0071 & 0 & 0 & 0.0071 & 0.0071 \\
\hline $\mathrm{Ti}$ & $\%$ & 0.0035 & 0 & 0 & 0.0035 & 0.0035 \\
\hline $\mathrm{V}$ & $\%$ & 0.138 & 0.0014 & 1.02 & 0.137 & 0.139 \\
\hline $\mathrm{W}$ & $\%$ & 0.071 & 0,0078 & 11.03 & 0.076 & 0.065 \\
\hline $\mathrm{Zn}$ & $\%$ & 0.0024 & 0 & 0 & 0.0024 & 0.0024 \\
\hline $\mathrm{Zr}$ & $\%$ & 0.0051 & 0.0002 & 0.2 & 0.0052 & 0.0049 \\
\hline $\mathrm{Se}$ & $\%$ & $<0.0005$ & 0.0001 & 4.42 & $<0.0005$ & $<0.0005$ \\
\hline $\mathrm{N}$ & $\%$ & 0.0093 & 0.00007 & 0.76 & 0.0092 & 0.0093 \\
\hline $\mathrm{Ca}$ & $\%$ & 0.0014 & 0.0001 & 10.1 & 0.0013 & 0.0015 \\
\hline $\mathrm{Te}$ & $\%$ & 0.0026 & 0.0025 & 97.91 & $<0.0010$ & 0.0044 \\
\hline $\mathrm{Fe}$ & $\%$ & 97.74 & 0 & 0 & 97.74 & 97.74 \\
\hline & & & & & & \\
\hline
\end{tabular}

\section{Preparation of $\mathrm{Zn}^{2+}$ solution}

$1 \mathrm{~g}$ of $\mathrm{ZnSO}_{4} .7 \mathrm{H}_{2} \mathrm{O}$ salt was dissolved in distilled water and made up to $250 \mathrm{ml} .5$ mlof this solution diluted to $100 \mathrm{ml}$ gives $50 \mathrm{ppm}$ of $\mathrm{Zn}^{2+}$.

\section{Weight loss method}

Weights of the three polished mild steel specimens were measured before and after immersion in various test solutions $(100 \mathrm{ml})$ The inhibition efficiencies were calculated from the relation.

$$
I E=\left[\left(C R_{1}-C R_{2}\right) / C R_{1}\right] 100 \%
$$

where,

$\mathrm{CR}_{1}$ is corrosion rate in the absence of inhibitor, and $\mathrm{CR}_{2}$ is the corrosion rate in the presence of inhibitor.

The immersion period was one day. The experiments were carried out at room temperature. Corrosion rate was calculated in mdd units:

Corrosion rate $(\mathrm{mdd})=$ (weight loss in $\mathrm{mg} \mathrm{x}$ surface area in $\mathrm{dm}^{2}$ ) / immersion period in days

\section{Synergism parameters}

To evaluate the synergistic effect existing between $\mathrm{Zn}^{2+}$ and soapnut extract, synergism parameters $\left(S_{l}\right)$ were calculated. If is parameter $\left(S_{l}\right)$ greater than 1 , it indicates the presence of synergistic effect, existing between $\mathrm{Zn}^{2+}$ and soapnut extract .To confirm this Synergism parameters $(\mathrm{SI})$ are calculated as shown, using the relation: 


$$
S_{I}=\left(1-\theta_{1+2}\right) /\left(1-\theta_{1+2}^{\prime}\right)
$$

where

$$
\theta_{1+2}=(\theta 1+\theta 2)-(\theta 1 \times \theta 2)
$$

$\theta_{1}=$ surface coverage by inhibitor 1 (soapnut extract)

$\theta_{2}=$ surface coverage by inhibitor $2\left(\mathrm{Zn}^{2+}\right)$

$\theta^{\prime}{ }_{1+2}=$ Combined surface coverage byinhibitors 1

and 2 .

\section{Langmuir adsorption isotherm}

There are various types of adsorption isotherms such as Langmuir, Freundlich and Temkin. In the case of Langmuir adsorption isotherm a plot of $C$ vs $C / \theta$ gives a straight line. Where $C$ is concentration of the inhibitor and $\theta$ is surface coverage

$$
\theta=\% \mid E / 100
$$

\section{Electrochemical study}

In the present work corrosion resistance of mild steel immersed in various test solutions were measured by Polarization study and AC impedance spectra.

\section{Polarization study}

Polarization studies were carried out in a $\mathrm{CHI}$ Electrochemical work station analyzer, model $660 \mathrm{~A}$. It was provided with automatic iR compensation facility. A three electrode cell assembly was used (Figure 3). A SCE was the reference electrode.

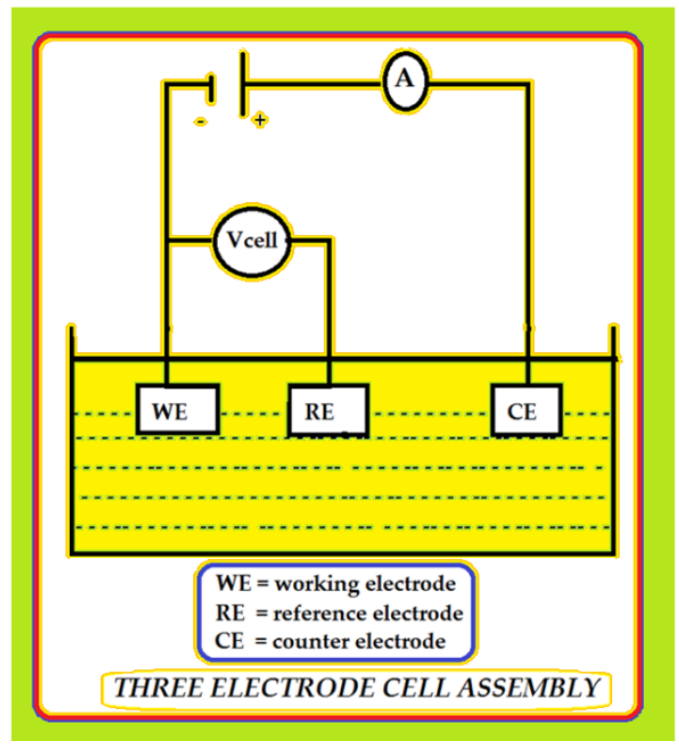

Figure 3. Threee lectrode cell assembly

Slika 3. Sklop ćelije sa tri elektrode

Platinum was the counter electrode. Mild steel was the working electrode. A time interval of 5 to
10 minutes was given for the system to attain a steady state open circuit potential. After having done IR compensation, polarization study was carried out at a sweep rate of $0.01 \mathrm{~V} / \mathrm{s}$. From polarization study, corrosion parameters such as corrosion potential $\left(E_{\text {corr }}\right)$, corrosion current ( $\left.I_{\text {corr }}\right)$, Tafel slopes anodic $=b_{a v}$ and cathodic $=b_{c}$ and LPR (linear polarisation resistance) values were measured.

\section{AC impedance spectra}

The same instrument and set-up used for polarization study were used to record $A C$ impedance spectra also. The real part ( $\left.Z^{\prime}\right)$ and imaginary part (-Z") of the cell impedance were measured in Ohms at various frequencies. AC impedance spectra were recorded with initial $E(V)=0$, high frequency $\left(\mathrm{Hz}=1 \times 10^{5}\right)$, low frequency $(\mathrm{Hz}=1)$, amplitude $(\mathrm{V})=0.005$ and quiet time $(\mathrm{s})=$ 2. From Nyquist plot the values of charge transfer resistance $\left(R_{t}\right)$ and the double layer capacitance $\left(\mathrm{C}_{\mathrm{dl}}\right)$ were calculated.

\section{Dynamic light scattering (DLS)}

Dynamic light scattering refers to measurement and interpretation of light scattering data on a microsecond time scale. Dynamic light scattering can be used to determine

- Particle/molecular size

- Size distribution

- Relaxations in complex fluids

- The experiments were carried out with particle size analyzer. Make : Micromeritics : Model : Nano plus

\section{Vickers hardness}

The carbon steel specimens immersed in various test solutions for one day were taken out, rinsed with double distilled water, dried and subjected to Vickers hardness measurement. The Vickers hardness measurements of the carbon steel surface were carried out by Shimadzu make model HMV-27.

\section{RESULTS AND DISCUSSION}

\section{Weight loss method}

Corrosion resistance of MS in well water, in presence of an inhibitor namely Soapnut extract in absence and presence of $\mathrm{Zn}^{2+}$ has been evaluated by weight loss method. The results are given in Table 3 and 4 . It is observed from the Table 3 that soapnut extract has some inhibition efficiency (IE). As the concentration of soapnut extract increases, surface coverage $(\theta)$ increases, corrosion rate (CR, mdd) decreases and inhibition efficiency (IE,\%) increases. 
Table 3. Inhibition of corrosion of mild steel immersed in well water (without Zinc)

Tabela 3. Inhibicija korozije mekog čelika uronjenog u bunarsku vodu (bez cinka)

\begin{tabular}{|c|c|c|c|c|}
\hline $\begin{array}{c}\text { Soapnut } \\
\text { extract } \\
(\mathrm{ml})\end{array}$ & $\begin{array}{c}\mathrm{Zn}^{2+} \\
(\mathrm{ppm})\end{array}$ & $\begin{array}{c}\text { Corrosion } \\
\text { rate }(\mathrm{mdd})\end{array}$ & $\begin{array}{c}\text { Inhibition } \\
\text { efficienc } \\
\mathrm{y}(\%)\end{array}$ & $\begin{array}{c}\text { Surface } \\
\text { coverag } \\
\mathrm{e}(\theta)\end{array}$ \\
\hline 0 & 0 & 14.86 & - & - \\
\hline 2 & 0 & 9.2132 & 38 & 0.38 \\
\hline 4 & 0 & 8.7674 & 41 & 0.41 \\
\hline 6 & 0 & 8.3216 & 44 & 0.44 \\
\hline 8 & 0 & 7.8758 & 47 & 0.47 \\
\hline 10 & 0 & 7.43 & 50 & 0.50 \\
\hline
\end{tabular}

Influence of addition of $\mathrm{Zn}^{2+}$ on the inhibition efficiency (IE, \%) of soapnut extract

Influence of addition of $\mathrm{Zn}^{2+}$ on the inhibition efficiency (IE, \%) of soapnut extract is given in Table 4. It is observed that in presence of $50 \mathrm{ppm}$ of $\mathrm{Zn}^{2+}$, the inhibition efficiency (IE, \%) of soapnut extract increases tremendously. A synergistic effect exists between soapnut extract and $\mathrm{Zn}^{2+}$. A mixture of inhibitors shows better inhibition efficiency (IE,\%) than that of individual members.

\section{Synergistic effect}

A mixture of inhibitors shows better inhibition efficiency (IE, \%) than that of individual members. For example, $50 \mathrm{ppm}$ of $\mathrm{Zn}^{2+}$ has $14 \%$ inhibition efficiency. $10 \mathrm{ml}$ of soapnut extract has $50 \%$ inhibition efficiency. But their combination has $97 \%$ inhibition efficiency.
Table 4. Inhibitionofcorrosion of mild steel immersed in well water (with Zinc)

Tabela 4. Inhibicija korozije mekog čelika uronjenog u bunarsku vodu (sa cinkom)

\begin{tabular}{|c|c|c|c|c|}
\hline $\begin{array}{c}\text { Soapnut } \\
\text { extract } \\
(\mathrm{ml})\end{array}$ & $\begin{array}{c}\mathrm{Zn}^{2+} \\
(\mathrm{ppm})\end{array}$ & $\begin{array}{c}\text { Corrosion } \\
\text { rate } \\
(\mathrm{mdd})\end{array}$ & $\begin{array}{c}\text { Inhibition } \\
\text { efficiency } \\
(\%)\end{array}$ & $\begin{array}{c}\text { Surface } \\
\text { coverage } \\
(\theta)\end{array}$ \\
\hline 0 & 0 & 14.86 & - & - \\
\hline 2 & 50 & 2.229 & 85 & 0.85 \\
\hline 4 & 50 & 1.7832 & 88 & 0.88 \\
\hline 6 & 50 & 1.3374 & 91 & 0.91 \\
\hline 8 & 50 & 0.8916 & 94 & 0.94 \\
\hline 10 & 50 & 0.4458 & 97 & 0.97 \\
\hline 0 & 50 & 12.7796 & 14 & 0.14 \\
\hline
\end{tabular}

This confirms the synergistic effect existing between soapnut extract and $\mathrm{Zn}^{2+}$ (Table 5).

Table 5. Synergistic effect existing between soapnut extract and $\mathrm{Zn}^{2+}$

Tabela 5. Sinergijski efekat koji postoji između ekstrakta sapuna i $\mathrm{Zn}^{2+}$

\begin{tabular}{|c|c|}
\hline System & Inhibition efficiency, \% \\
\hline $50 \mathrm{ppm}$ of $\mathrm{Zn}^{2+}$ & 14 \\
\hline $10 \mathrm{ml}$ of soapnut extract & 50 \\
\hline $\begin{array}{c}50 \mathrm{ppm} \text { of } \mathrm{Zn}^{2+} \text { and } 10 \mathrm{ml} \\
\text { of soapnut extract }\end{array}$ & 97 \\
\hline
\end{tabular}

\section{mild steel}

$50 \mathrm{ppm}$ of $\mathrm{Zn2}+$ and $10 \mathrm{ml}$ of soapnut extract

$10 \mathrm{ml}$ of soapnut extract

$50 \mathrm{ppm}$ of $\mathrm{Zn2+}$

\section{Synergistic effect}

Inhibition efficiency, \%

Figure 3. Synergistic effect

Slika 3. Sinergijski efekat 


\section{Synergism parameters}

When two substances are used as corrosion inhibitors, synergistic effect is noticed between them. That is, a mixture of inhibitors shows better inhibition efficiency (IE, \%) than that of individual members [18-21]. Synergism parameters $\left(S_{I}\right)$ are calculated. If there is synergistic effect, the Synergism parameter $\left(S_{l}\right)$ will be greater than 1 . The Synergism parameters $\left(\mathrm{S}_{\mathrm{I}}\right)$ calculated for various combinations of $10 \mathrm{ml}$ of soapnut extract and (50 ppm of $\mathrm{Zn}^{2+}$ ) are given in Table 6 .

\section{Langmuir adsorption isotherm}

\section{Soapnut extract system}

The plot of $C$ vs $C / \theta$ gives a straight line with $R^{2}$ value of 0.993 (Figure 4). Thus it is inferred that the adsorption soapnut extract on the metal surface obeys Langmuir adsorption isotherm.
Table 6. Synergism parameters

Tabela 6. Parametri sinergizma

\begin{tabular}{|c|c|c|c|c|c|}
\hline $\begin{array}{c}\text { Soapnut } \\
\text { extract, } \mathrm{ml}\end{array}$ & $\theta_{1}$ & $\theta^{\prime}{ }+2$ & $\theta_{2}$ & $\theta_{1+2}$ & $\mathrm{~S}_{\mathrm{I}}$ \\
\hline 2 & 0.38 & 0.85 & 0.14 & 0.4668 & 3.56 \\
\hline 4 & 0.41 & 0.88 & 0.14 & 0.4926 & 4.29 \\
\hline 6 & 0.44 & 0.91 & 0.14 & 0.5184 & 5.35 \\
\hline 8 & 0.47 & 0.94 & 0.14 & 0.5442 & 7.60 \\
\hline 10 & 0.50 & 0.97 & 0.14 & 0.57 & 14.33 \\
\hline
\end{tabular}

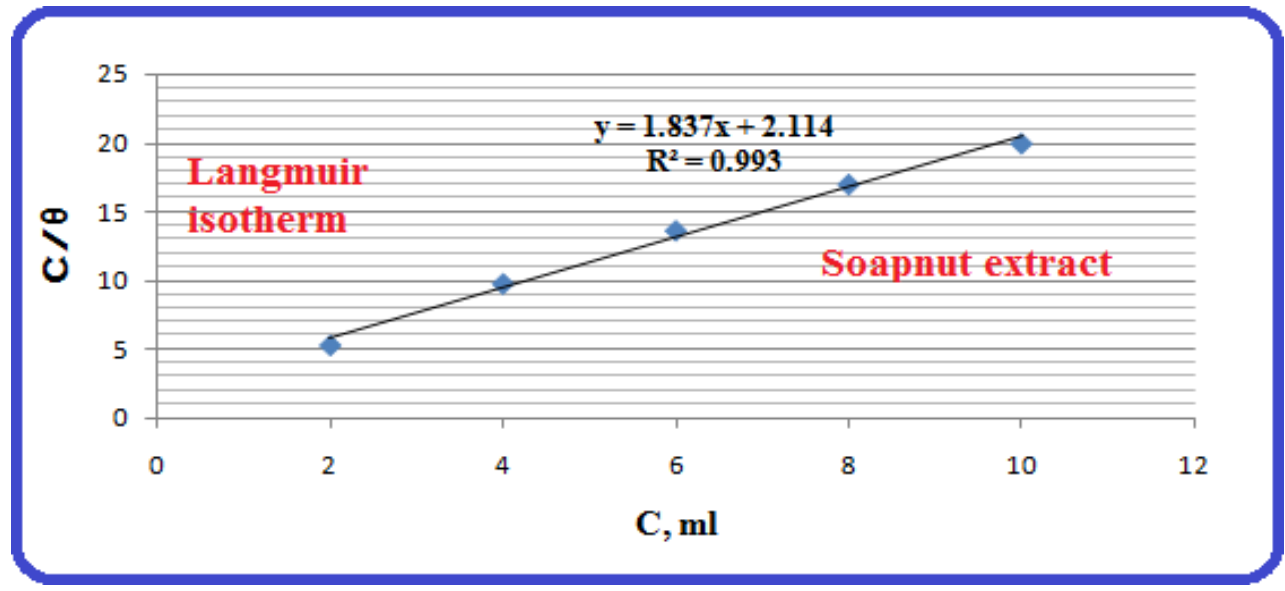

Figure 4. Langmuir adsorption isotherm for soapnut extract

Slika 4. Langmirova izoterma adsorpcije za ekstrakt sapuna

Soapnut extract $-\mathrm{Zn}^{2+}$ system

The plot of $C$ vs $C / \theta$ gives a straight line with $R^{2}$ value of 0.998 (Figure 5). Thus it is inferred that the adsorption soapnut extract, in presence of $\mathrm{Zn}^{2+}$, on the metal surface obeys Langmuir adsorption isotherm.

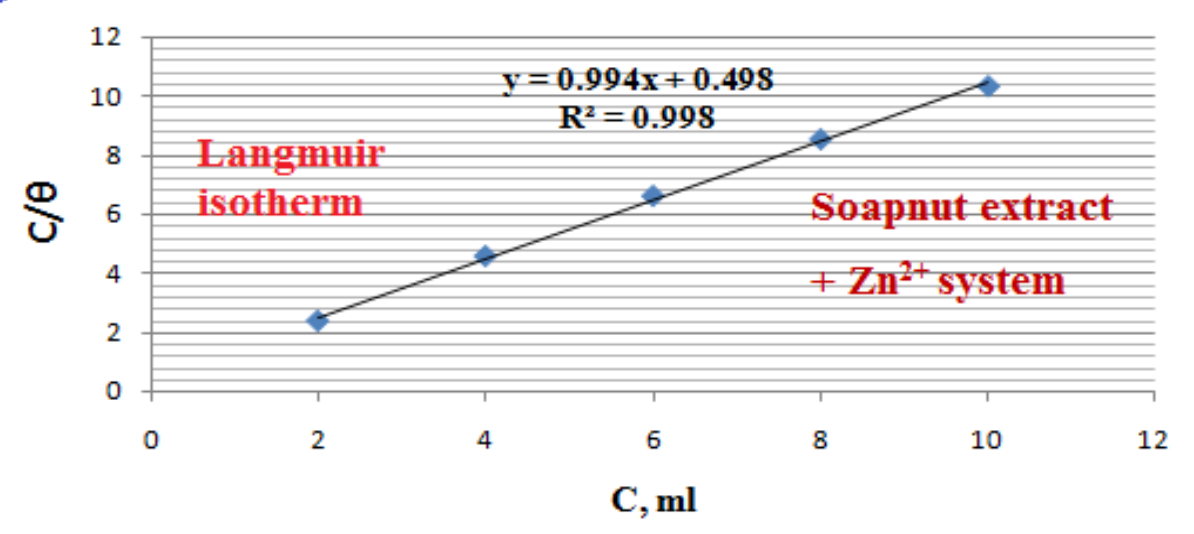

Figure 5. Langmuir adsorption isotherm for soapnut extract - $\mathrm{Zn}^{2+}$ system

Slika 5. Langmirova izoterma adsorpcije za ekstrakt sapun - $\mathrm{Zn}^{2+}$ sistem 


\section{Analysis of polarization study}

Corrosion parameters derived from polarization study, namely corrosion potential ( $\left.E_{\text {corr }}\right)$, Tafel slope $\left(b_{c}, b_{a}\right)$, Linear Polarisation Resistance (LPR) values and Corrosion Current $\left(\mathrm{I}_{\text {corr }}\right)$ values are given in Table 7 . The polarisation curves of mild steel immersed in well water in the absence and presence of inhibitor system are shown in Figure 6.

It is observed from the Table 7 that when mild steel is immersed in well water, the corrosion potential is $-751 \mathrm{mV}$ vs SCE, the LPR value is $7110 \mathrm{hmcm}^{2}$. The corrosion current value is $6.082 \times 10^{-5} \mathrm{~A} / \mathrm{cm}^{2}$. It is inferred from the Table 7 , that in presence of inhibitor, the corrosion potential is shifted from $-751 \mathrm{mV}$ to- $549 \mathrm{mV}$ vs SCE. This indicates that a film is formed on the anodic sites of the metal surface. It suggests that the inhibitor system (soapnut extract $-\mathrm{Zn}^{2+}$ ) functions as anodic type inhibitor system [22,23]. The LPR value increases from $7110 \mathrm{hmcm}^{2}$ to $14270 \mathrm{hmcm}^{2}$. Correspondingly the corrosion current value decreases from $6.082 \times 10^{-5} \mathrm{~A} / \mathrm{cm}^{2}$ to $3.066 \times 10^{-5}$ $\mathrm{A} / \mathrm{cm}^{2}$. These observations confirm that a protective film is formed on the metal surface. This controls the corrosion of metal. If a protective film is formed on the metal surface, LPR value increases and corrosion current decreases.

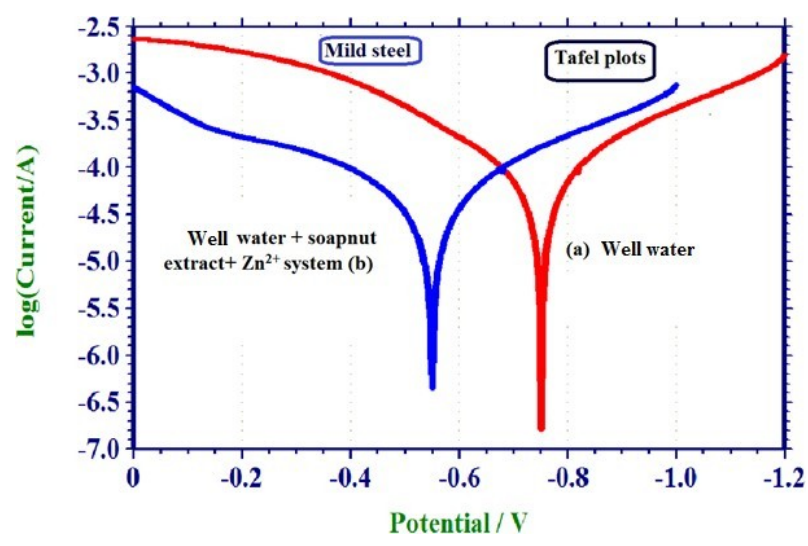

Figure 6. Polarization curves of mild steel immersed in various test solutions (a) well water,

(b) well water + soapnut extract $+\mathrm{Zn}^{2+}$ system

Slika 6. Polarizacione krive mekog čelika uronjenog u različite test rastvore (a) bunarsku vodu, (b) bunarsku vodu + ekstrakt sapun $+Z^{2+}$ sistem

Table 7. Corrosion parameters of mild steel immersed in well water in theabsence and presence of inhibitor system [soapnut extract- $\mathrm{Zn}^{2+}$ ] obtained by polarization study

Tabela 7. Parametri korozije mekog čelika uronjenog u bunarsku vodu u odsustvu i prisustvu inhibitorskog sistema [ekstrakt sapuna- $\mathrm{Zn}^{2+}$ ] dobijeni ispitivanjem polarizacije

\begin{tabular}{|c|c|c|c|c|c|}
\hline System & $\begin{array}{c}\mathbf{E}_{\text {corr }} \\
\mathbf{m V} \text { vs SCE }\end{array}$ & $\begin{array}{c}\mathbf{b}_{\mathbf{c}} \\
\mathbf{m V / d e c a d e}\end{array}$ & $\begin{array}{c}\mathbf{b}_{\mathbf{a}} \\
\mathbf{m V / d e c a d e}\end{array}$ & $\begin{array}{c}\text { LPR } \\
\text { Ohm }_{\mathbf{c m}} \mathbf{2}^{\mathbf{2}}\end{array}$ & $\begin{array}{c}\mathbf{I}_{\text {corr }} \\
\mathbf{A} / \mathbf{c m}^{\mathbf{2}}\end{array}$ \\
\hline Well water & -751 & 195 & 169 & 711 & $6.082 \times 10^{-5}$ \\
\hline $\begin{array}{c}\text { Well water + soapnut extract }(10 \\
\mathrm{ml})+\mathrm{Zn}^{2+}(50 \mathrm{ppm})\end{array}$ & -549 & 190 & 214 & 1427 & $3.066 \times 10^{-5}$ \\
\hline
\end{tabular}

\section{Analysis of AC impedance spectra}

The protective film formed on the metal surface is confirmed by ACimpedance spectra. If a protective film is formed on the metal surface, the charge transfer resistance $\left(R_{t}\right)$ value increases; double layer capacitance value $\left(\mathrm{C}_{\mathrm{dl}}\right)$ decreases and the impedance $[\log (\mathrm{Z} / \mathrm{ohm})]$ value increases.

The AC impedance spectra of mild steel immersed in well water in the absence and presence of inhibitor [soapnut (sapindus trifoliatus) extract $-\mathrm{Zn}^{2+}$ ] are shown in Figure7. (Nyquist plots), Figures $8 \mathrm{a}$ and $8 \mathrm{~b}$ (Bode plots). The corrosion parameters, namely $R_{t}, C_{d l}$, phase angle and impedance values are given in Table 8 . It is observed from the Table 8 that, when mild steel is immersed in well water, the $R_{t}$ value is 129.81 $\mathrm{Ohmcm}^{2}$.

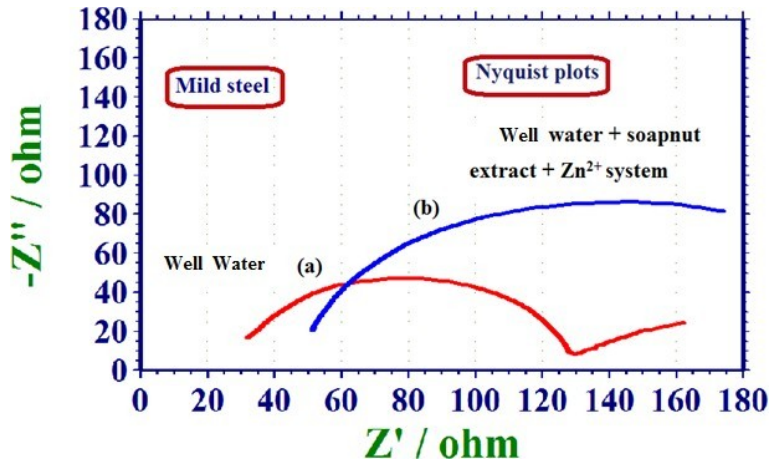

Figure 7. AC impedance spectra of mild steel immersed in various test solutions (a) well water,

(b) well water + soapnut extract $+\mathrm{Zn}^{2+}$ system

Slika 7. Spektri impedanse naizmenične struje mekog čelika uronjenog u različite test rastvore (a)

bunarsku vodu, (b) bunarsku vodu + ekstrakt sapuna $+\mathrm{Zn}^{2+}$ sistem 
The $\mathrm{C}_{\mathrm{dl}}$ value is $3.929 \times 10^{-8} \mathrm{~F} / \mathrm{cm}^{2}$. The impedance value is 2.213 . The phase angle value is 37.35 . In the presence of inhibitor system, the $R_{t}$ value increases from $129.81 \mathrm{Ohmcm}^{2}$ to 398.57
$\mathrm{Ohmcm}^{2}$. The $\mathrm{C}_{\mathrm{dl}}$ value decreases from $3.929 \times 10^{-8}$ $\mathrm{F} / \mathrm{cm}^{2}$ to $1.2795 \times 10^{-9} \mathrm{~F} / \mathrm{cm}^{2}$. The impedance value increases from 4.084 to 4.153 . The phase angle value increases from 37.35 to 39.12 [24,25].
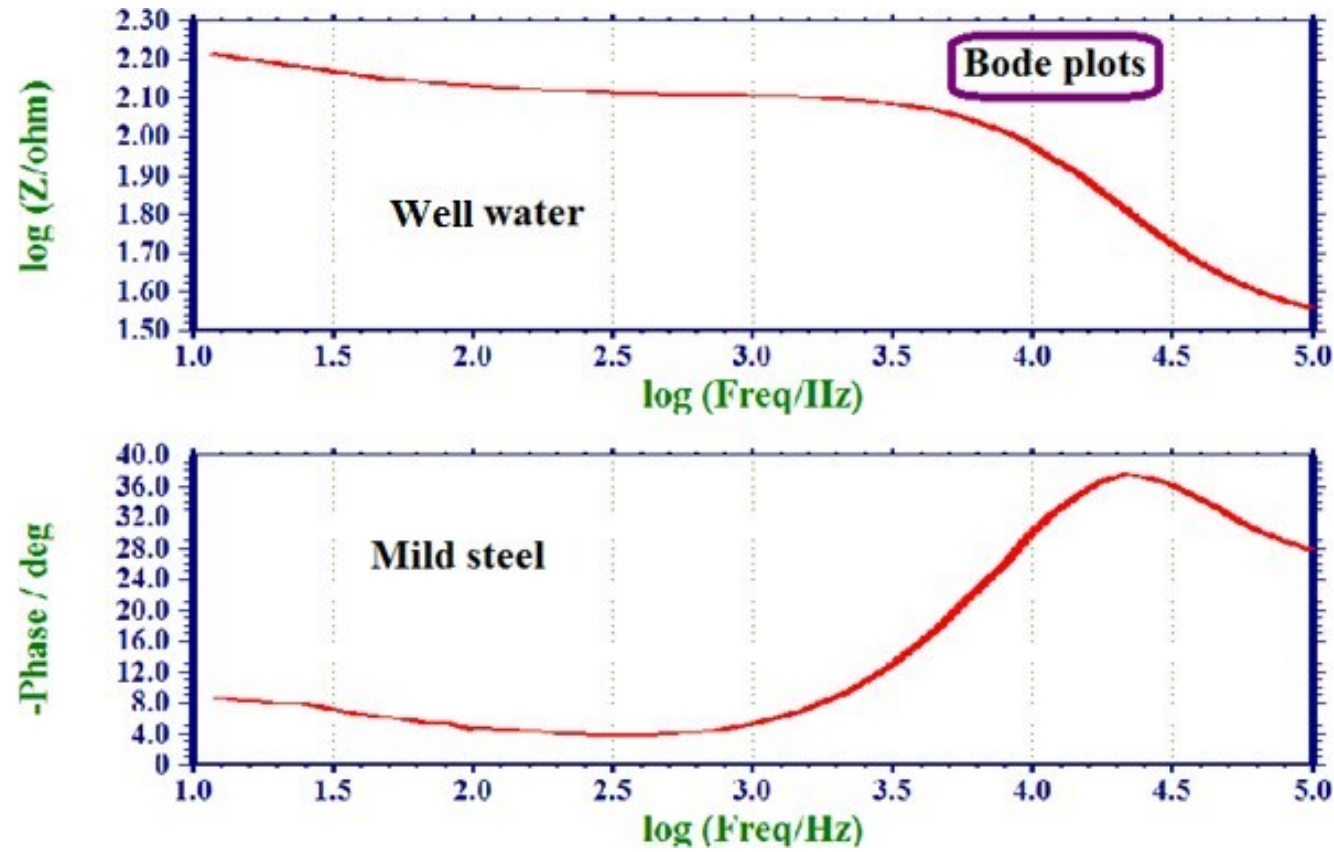

Figure 8a. AC impedance spectra of mild steel immersed in well water (Bode plots)

Slika 8a. Spektri impedanse naizmenične struje mekog čelika uronjenog u bunarsku vodu (Bode grafike)
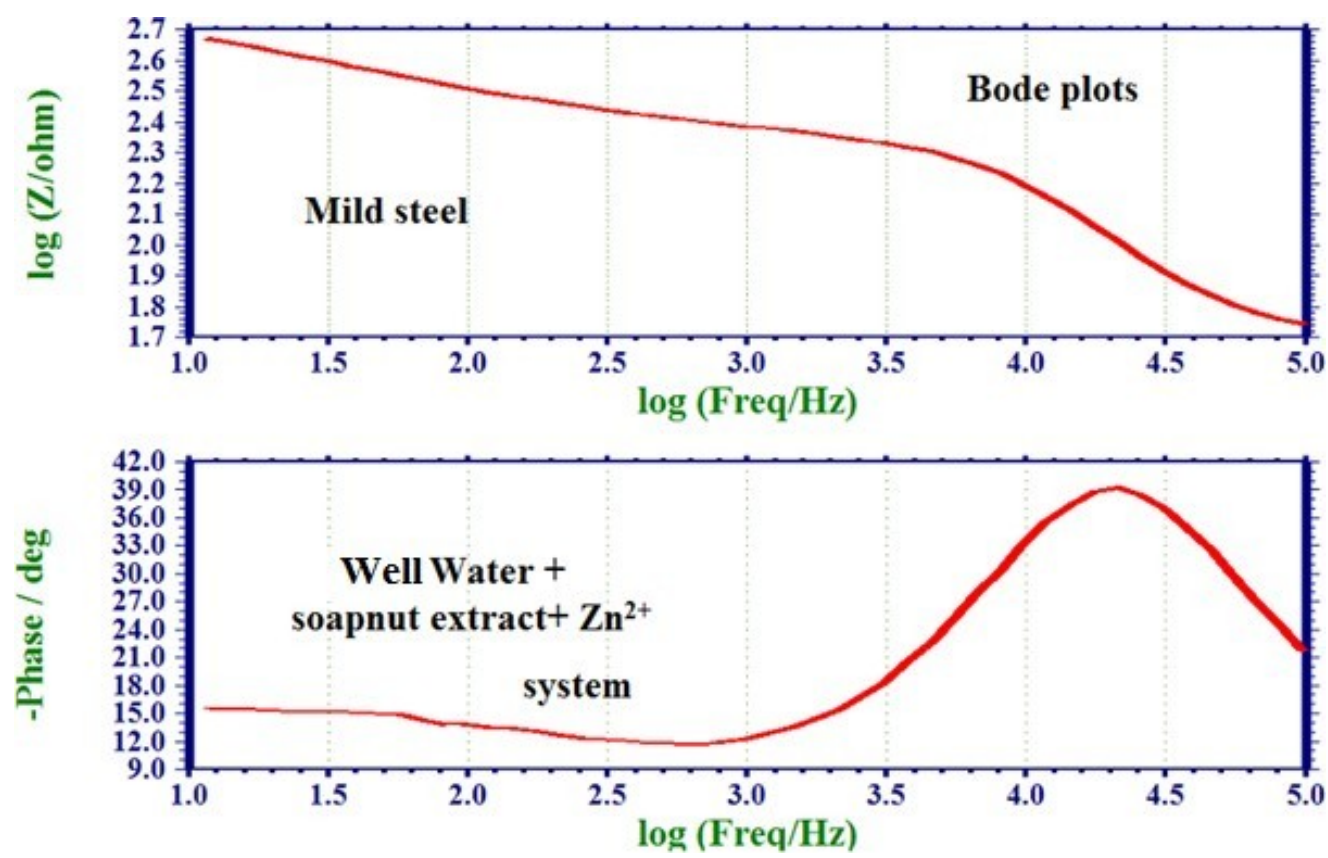

Figure 8b. AC impedance spectra of mild steel immersed in well water + soapnut extract $+\mathrm{Zn}^{2+}$ system (Bode plots)

Slika 8b. Spektri impedanse naizmenične struje mekog čelika uronjenog u bunarsku vodu + ekstrakt sapuna $+\mathrm{Zn}^{2+}$ sistem (Bode grafikoni) 
Table 8. Corrosion parameters of mild steel immersed in well water in the absence and presence of inhibitor system (Soapnut extract $-\mathrm{Zn}^{2+}$ ) obtained by AC impedance spectra

Tabela 8. Parametri korozije mekog čelika uronjenog u bunarsku vodu u odsustvu i prisustvu inhibitornog sistema (ekstrakt soapnut - $\mathrm{Zn}^{2+}$ ) dobijeni spektrom impedanse naizmenične struje

\begin{tabular}{|l|c|c|c|c|}
\hline \multicolumn{1}{|c|}{ System } & $\begin{array}{c}\mathbf{R}_{\mathbf{t}} \\
\text { Ohmcm }\end{array}$ & $\begin{array}{c}\mathbf{C}_{\mathbf{d l}} \\
\mathbf{F} / \mathbf{c m}^{2}\end{array}$ & $\begin{array}{c}\text { Impedance } \\
\text { log(Z/Ohm })\end{array}$ & $\begin{array}{c}\text { Phase angle } \\
\left.\mathbf{(}^{\circ}\right)\end{array}$ \\
\hline Well water & 129.81 & $3.929 \times 10^{-8}$ & 2.213 & 37.35 \\
\hline Well water + soapnut extract $(10 \mathrm{ml})+\mathrm{Zn}^{2+}(50 \mathrm{ppm})$ & 398.57 & $1.2795 \times 10^{-8}$ & 2.667 & 39.12 \\
\hline
\end{tabular}

\section{Equivalent circuit diagrams}

The Nyquist plot of the blank system is characteristic of a film forming and film breaking system. The inhibited system has one time constant. The equivalent circuit diagrams shown in Figures 9 and 10.

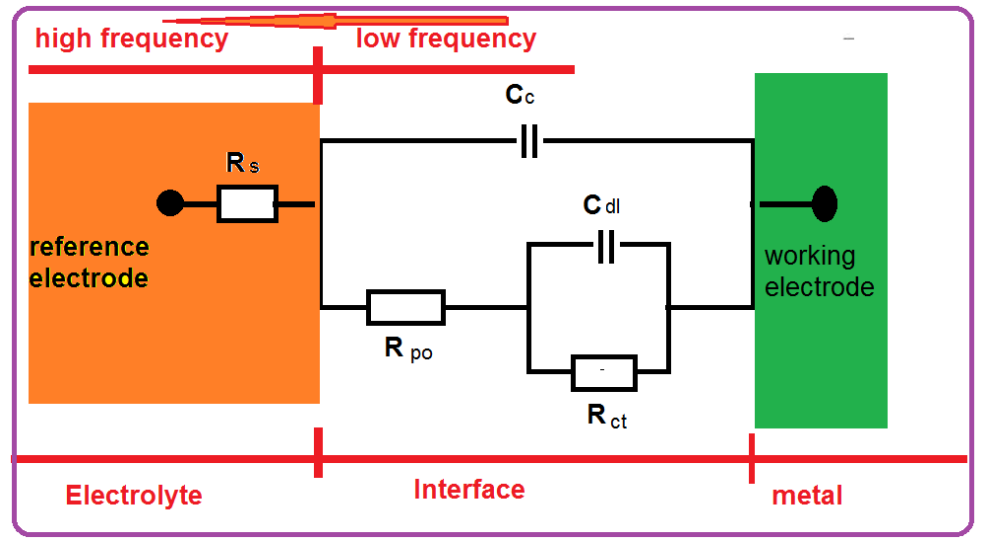

Figure 9. Equivalent circuit diagram for blank system (film formation and film breaking)

Slika 9. Ekvivalentna šema za blank sistem (formiranje filma i lomljenje filma)

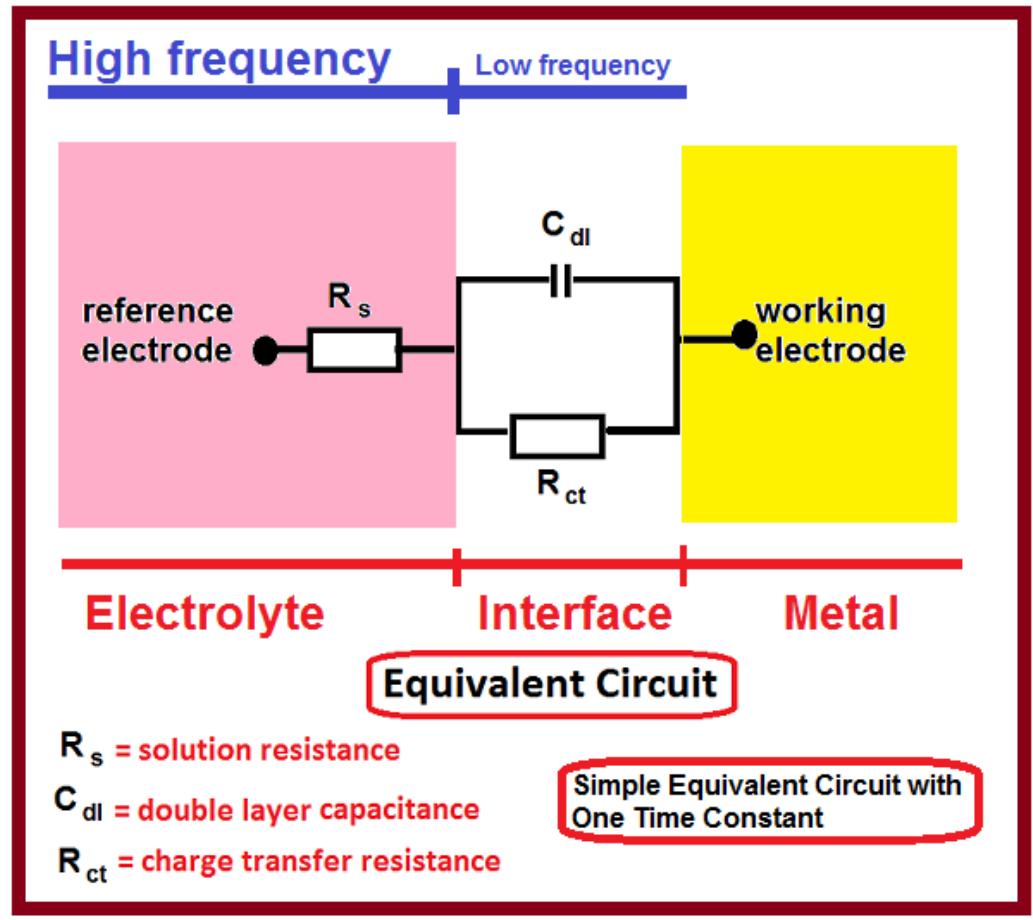

Figure10. Equivalent circuit diagram for inhibited system (one time constant)

Slika 10. Ekvivalentna šema kola za blokirani sistem (jedna vremenska konstanta) 


\section{Dynamic light scattering}

The particle size of protective film ranges from 30-990 nm. The size of the protective and the polydispersity index have been calculated by dynamic light scattering method. The results are shown in Figures11 and 12 and Table 9,10,11.

The average diameter of protective film is $148.7 \mathrm{~nm}$. This is the width in the nanometer scale. The polydispersity index is 0.240 . This indicates homogeneous nature of the protective film. The diffusion constant is $3.308 \times 10^{-8}\left(\mathrm{~cm}^{2} / \mathrm{sec}\right)$. The intensity distribution curve is shown in Figure 11. ACF of soapnut extract- $\mathrm{Zn}^{2+}$ system is shown in Figure 12.
Table 9. Distribution Results

Tabela 9. Rezultati

\begin{tabular}{|c|c|c|}
\hline Peak & Diameter $(\mathbf{n m})$ & Std. Dev \\
\hline 1 & 234.8 & 183.9 \\
\hline 2 & 0.0 & 0.0 \\
\hline 3 & 0.0 & 0.0 \\
\hline 4 & 0.0 & 0.0 \\
\hline 5 & 0.0 & 0.0 \\
\hline Average & 234.8 & 183.9 \\
\hline Residual & $1.958 \mathrm{e}-003$ & $(\mathrm{O} . \mathrm{K})$ \\
\hline
\end{tabular}

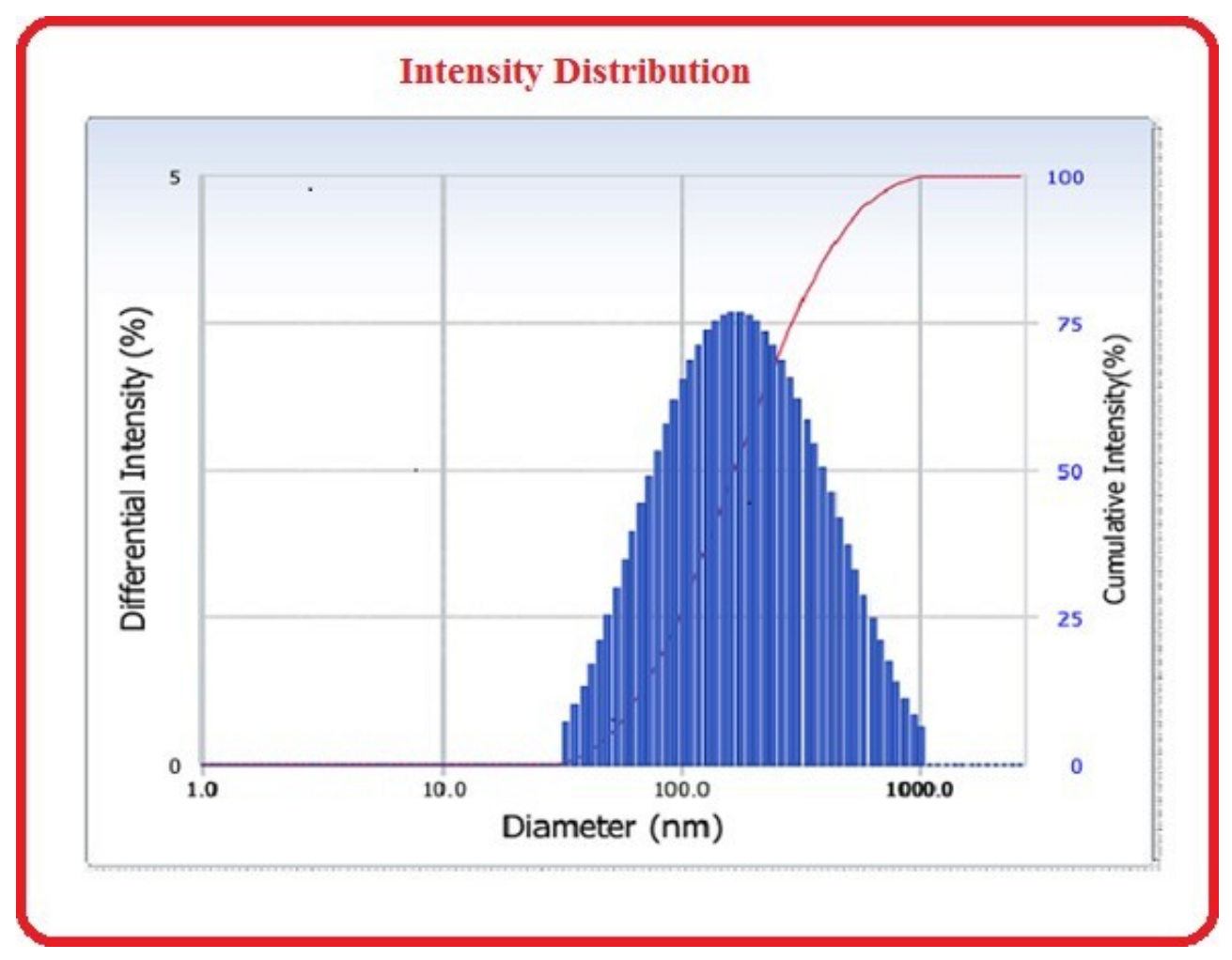

Figure 11. Intensity distribution curve

Slika 11. Kriva raspodele intenziteta

Table 10. Cumulants Results

Tabela 10. Kumulativni rezultati

\begin{tabular}{|c|c|}
\hline Diameter (d) & $148.7(\mathrm{~nm})$ \\
\hline Polydispersity Index (P.I.) & 0.240 \\
\hline Diffusion constant (D) & $3.308 \mathrm{e}-008\left(\mathrm{~cm}^{2} / \mathrm{sec}\right)$ \\
\hline
\end{tabular}

Table 11. Measurement condition

Tabela 11. Uslovi merenja

\begin{tabular}{|c|c|}
\hline Diluent name & Water \\
\hline Refractive Index & 1.3328 \\
\hline Temperature & $25^{\circ} \mathrm{C}$ \\
\hline Viscosity & $0.8878(\mathrm{cP})$ \\
\hline Scattering Intensity & $31311(\mathrm{cps})$ \\
\hline Attenuator 1 & $12.61 \%$ \\
\hline
\end{tabular}




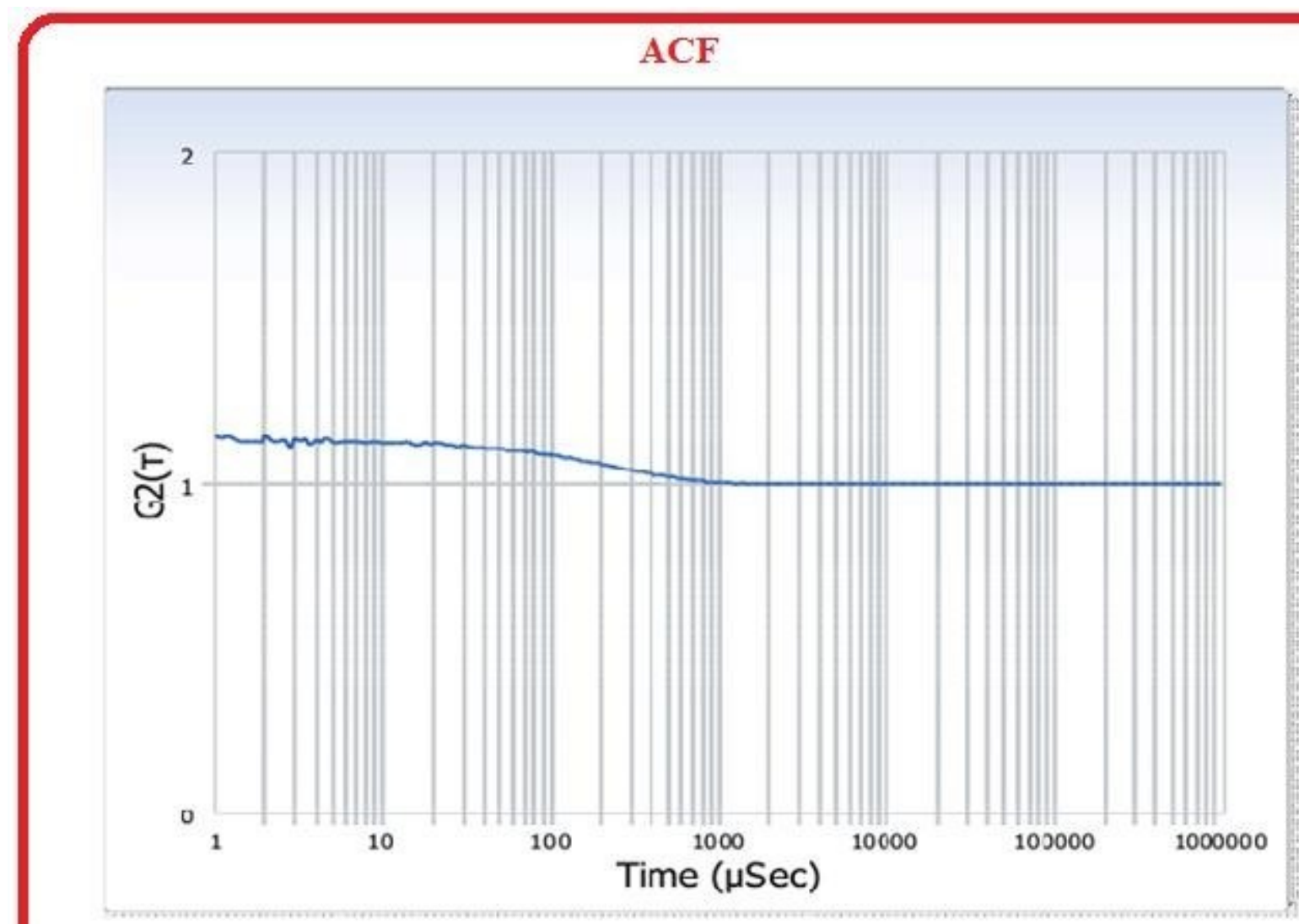

Figure 12. ACF of soapnut extract- $Z n^{2+}$ system

Slika 12. ACF ekstrakta sapun - $\mathrm{Zn}^{2+}$ sistem

\section{Analysis of Vickers hardness}

The Vickers test is often easier to use than other hardness tests since the required calculations are independent of the size of the indenter, and the indenter can be used for all materials irrespective of hardness. The basic principle, as with all common measures of hardness, is to observe a material's ability to resist plastic deformation from a standard source. The Vickers test can be used for all metals and has one of the widest scales among hardness tests. The unit of hardness given by the test is known as the Vickers Pyramid Number (HV).

The hardness was measured for polished mild steel surface (systemA), polished mild steel surface immersed in corrosive medium (well water) (system $B$ ) and polished mild steel surface immersed in corrosive medium (well water) containing the inhibitor system (system $C$ ). The values are given in Table 12. It is observed that for system $A$ the hardness is high. For system B the hardness is low, because the corroded surface contains iron oxide film which is porous and amorphous. The surface is very rough. Pits are noticed due to corrosion. For system $C$ the surface is smooth, due to the formation of protective film (Figure 13). Usually the hardness is in between that of system $A$ and $B$. That is, lower than that of polished metal but higher than that of corroded surface. This is due to the formation of a protective film $f$ on the metal during corrosion inhibition process. The protective film consists of iron inhibitor (active principles) complex. Thus the Vickers hardness is used in corrosion inhibition study. Weight loss method reveals that addition of $10 \mathrm{ml}$ of $10 \%$ soapnut extract offers an inhibition efficiency of 97 $\%$ to carbon steel immersed in well water.

Table 12. HV for 300 gram load

Tabela 12. HV za opterećenje od 300 grama

\begin{tabular}{|c|c|c|c|c|}
\hline System & Load & L1 & L2 & HV \\
\hline Polished metal & $300 \mathrm{~g}$ & 54.90 & 55.29 & 183 \\
\hline Corroded metal & $300 \mathrm{~g}$ & 70.27 & 72.59 & 109 \\
\hline Inhibited metal & $300 \mathrm{~g}$ & 60.29 & 61.66 & 150 \\
\hline
\end{tabular}




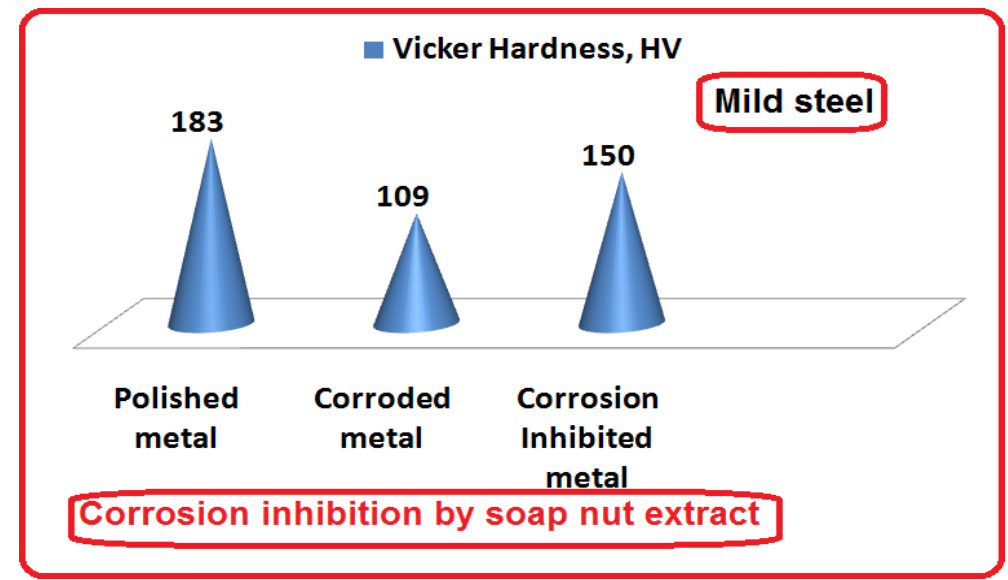

Figure 13. Hardness of various surfaces (300 g load)

Slika 13. Tvrdoća raznih površina (opterećenje 300 g)

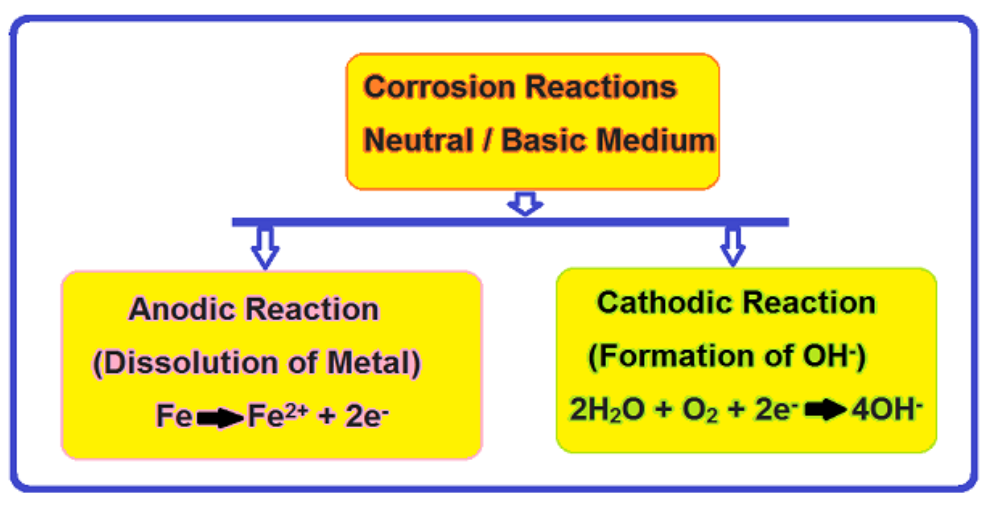

Figure 14. Anodic and cathodic reactions in corrosion process

Slika 14. Anodne i katodne reakcije u procesu korozije

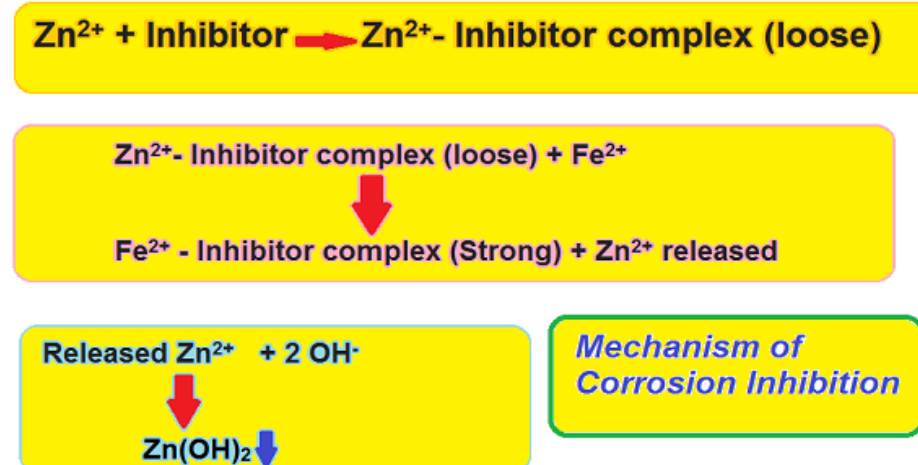

Figure 15. Mechanism of corrosion inhibition

Slika 15. Mehanizam inhibicije korozije

Mechanism of corrosion inhibition

In presence of $\mathrm{Zn}^{2+}$ corrosion resistance of the metal further increases (better than the inhibitor system alone), which is supported by the fact that the linear polarisation resistance value further increases and corrosion current value further decreases. Similarly during electrochemical impedance study, charge transfer value increases tremendously and double layer capacitance value decreases to a great extent. It is inferred that in presence of $\mathrm{Zn}^{2+}$, more inhibitor molecules (active ingredients of the plant extract ) are transported 
towards the metal surface, as $\mathrm{Zn}^{2+}-$ inhibitor complex. On the metal surface iron inhibitor complex is formed on the anodic sites of the metal surface and $\mathrm{Zn}^{2+}$ is released. The released $\mathrm{Zn}^{2+}$ combines with $\mathrm{OH}-$ to form $\mathrm{Zn}(\mathrm{OH})_{2}$ complex on the cathodic sites of the metal surface. Thus in presence of $\mathrm{Zn}^{2+}$, both anodic reaction and cathodic reaction are controlled effectively. This accounts for the increase in corrosion resistance of metal well water in presence of inhibitor and $\mathrm{Zn}^{2+}$. In presence of $\mathrm{Zn}^{2+}$ and inhibitor a loose complex is formed between $\mathrm{Zn}^{2+}$ and inhibitor. The bond between them is strong enough to carry the inhibitor to the metal surface and weak enough to release the inhibitor in presence of $\mathrm{Fe}^{2+}$ to form $\mathrm{Fe}^{2+}$-inhibitor complex on the anodic sites of the metal surface (Figures 14 and 15).

\section{CONCLUSIONS}

Useful conclusions are derived from the interpretation of the experimental data.

- Weight loss method reveals that soapnut extract$\mathrm{Zn}^{2+}$ system offers a maximum corrosion inhibition efficiency of $97 \%$ in controlling corrosion of mild steel in well water.

- Synergism parameters are found to be greater than 1 , confirming the

- synergistic effect existing between soapnut extract and $\mathrm{Zn}^{2+}$.

- Langmuir adsorption isotherm: Adsorption of inhibitor molecules

- on the metal surface obeys Langmuir adsorption isotherm.

- Polarisation Study reveals that the inhibitors namely aqueous extract of soapnut extract- $\mathrm{Zn}^{2+}$ system functions as anodic type of inhibitor.

- AC impedance spectra confirm the formation of a protective film on the metal surface.

- The DLS study reveals that the protective film formed on the surface is in nanometer scale.

- The hardness of metal surface increases in inhibitor system. It has been measured by Vickers Hardness.

- This formulation of soapnut extract- $\mathrm{Zn}^{2+}$ may be used in cooling water systems, where mild steel pipelines are used to carry well water which is used ascoolant.

\section{REFERENCES}

[1] T.Sathiyapriya, G.Rathika (2019) Corrosion inhibition efficiency of human black hair extract on mild steel in $1 \mathrm{M} \mathrm{H}_{2} \mathrm{SO}_{4}$ media, Indian Journal of Chemical Technology, 26, 216-223.

[2] B.N.Grgur (2020) Corrosion of the stainless steel $316 \mathrm{Ti}$ in $10 \%$ hydrochloric and sulfuric acid, Zastita Materijala, 61(4), 339-346.
[3] S.Rajendran, V.Sribharathy, A.Krishnaveni, J.Jeyasundari, J.Sathiyabama, T.S.Muthumegala, M.Manivannan (2011) Inhibition effect of self assembled films formed by adipic acid molecules on carbon steel surface, Zastita materijala, 52(3), 163-172.

[4] S.Sheetal, A.Prakash, Y.Raj, M.Harilal, J.Felix Kumar (2020) A review on the Enhanced Corrosion Control of Mild Steel in an Acidic Medium using Green Inhibitors, International Research Journal of Engineering and Technology (IRJET), 7(6), 40854093.

[5] A.El-Aziz S.Fouda, A.Y.El-Khateeb, N.M. Elbahrawi (2017) Cupressus sempervirens extract as green inhibitor for corrosion of carbon steel in hydrochloric acid solutions, Zastita Materijala, 60 (2), 129-146.

[6] A.El-Aziz S. Fouda, A.H.Ali (2018) Egy- dronate drug as promising corrosion inhibitor of $C$ - steel in aqueous medium, Zastita Materijala, 59 (1), 126140.

[7] P.Shanthy, J.A.Thangakani, S.Karthika, S.C. Joycee, S.Rajendran, J.Jeyasundari (2021) Corrosion inhibition by an aqueous extract of Ervatamia divaricate, International Journal of corrosion and Scale Inhibition, 10(1), 331-348.

[8] H.Zhang, Z.Ni, H.Wu, P.Xu, Z.Li, W.Zhang, H. Huang, Q.Zhou, X.Yue, Ji.Bao, X.Li (2020) Corrosion Inhibition of Carbon Steel in Hydrochloric Acid by Chrysanthemum Indicum Extract, International Journal of Electrochemical Science, 15, 5487 - 5499.

[9] K.Riaz Ahamed, B.Arifa Farzana, S.J.Diraviam, R. Dorothy, S.Rajendran, A.Al-Hashem (2019) Mild Steel Corrosion nhibition by the Aqueous Extract of Commelina benghalensis Leaves, Portugaliae Electrochimica Acta, 37(1), 51-70.

[10] G.I.Udom, G.A.Cookey, A.A.Abia (2017) The Effect of Acanthus montanus Leaves Extract on Corrosion of Aluminium in Hydrochloric Acid Medium, Current Journal of Applied Science and Technology, 25(2), 1-11.

[11] S.Rajendran, M.Agasta, R.B.Devi, B.S.Devi, K. Rajam, J.Jeyasundari (2009) Corrosion inhibition by an aqueous extract of Henna leaves (Lawsonia Inermis $L$ ), Zastita Materijala, 50, 77-84.

[12] H.Gerengi, II.Uygur, M.Solomon, M.Yildiz, H.Goksu (2016) Evaluation of the inhibitive effect of Diospyros kaki (Persimmon) leavesextract on St37 steel corrosion in acid medium, Sustainable Chemistry and Pharmacy, 4, 57-66.

[13] Ab.Khadraoui, Ab.Khelifa, K.Hachama, $H$. Boutoumi, B.Hammouti (2015) Synergistic effect of potassium iodide in controlling the corrosion of steel in acid medium by Mentha pulegium extract, Res Chem Intermed, 41, 7973-7980.

[14] H.M.Elabbasy, S.M.Zidan, Abd El-Aziz S. Fouda (2019) Inhibitive behavior of ambrosia maritima extract as an eco-friendly corrosion inhibitor for carbon steel in $1 \mathrm{M} \mathrm{HCl}$, Zastita Materijala, 59 (1), 126-140. 
[15] K.Hema, B.R.Venkatraman, A.Sirajunnisa, A. Subramania (2015) The Effect of Solanam Xanthocarpum Leaves Extract on Corrosion Inhibition of Carbon Steel in Acidic Medium, International Journal of Advanced Research in Chemical Science, 2(9), 10-20.

[16] E.Zentner (2011) Effects of phytogenic feed additives containing quillaja saponaria onammonia in fattening pigs (PDF), Retrieved 27 November 2012

[17] M.Sangeetha, S.Rajendran, N.Pavazhanayagam, C.Sobiga, P.Valentine Nancy (2016) Corrosion resistance of SS $316 \mathrm{~L}$ alloy in artificial saliva in the presence of a soft drink, Der Pharma Chemica, 8 , 334-337.

[18] A.M.Ridhwan, A.A.Rahim, A.M.Shah (2012) Synergistic effect of halide ions on the corrosion inhibition of mild steel in hydrochloric acid using mangrove tannin. International Journal of Electrochemical science, 7, 8091-8104.

[19] K.S.Shaju, K.Joby Thomas, V.P.Raphael, A.Paul (2012) Synergistic effect of KI on corrosion inhibition of mild steel by polynuclear Schiff base in sulphuric acid, Corrosion, 1-8, Article ID 425878.

[20] K.Aramaki, M.Hackerman (1969) Inhibition mechanism of medium sized polymethyleneimine,
Journal of the electrochemical society, 116(5), 568574.

[21] V.R.Nazeera Banu, V.Ramesh Babu, S.Rajendran (2017) Investigating the corrosion inhibition efficiency of surgical carbon steel instruments used in medical field, International Research Journal of Pharmacy, 8(12), 79-90.

[22] M.Lavanyaa, M.Suganya (2016) Comparative analysis of corrosion inhibition studies on various metals in oil well water using trisodium citrate as inhibitor, International Journal of Nano Corrosion Science and Engineering, 3(4), 88-103.

[23] D.Lakshmi, J.Sathiyabama, S.Rajendran (2017) The inhibition effect of o-nitrophenol and $\mathrm{Zn2+}$ system on corrosion of aluminium, International Journal of Corrosion and Scale Inhibition, 6(3), 240261.

[24] K.Anuradha, R.Vimala, B.Narayanasamy, J.Arockia Selvi, S.Rajendran (2008) Corrosion Inhibition of Carbon Steel in Low Chloride Media by an Aqueous Extract of Hibiscus rosa-sinensis Linn, Chem. Eng. Comm., 195, 352-366.

[25] A.Suriya Prabha, K.Kavitha, H.Benita Sherine, S.Rajendran (2020) Inhibition of corrosion of mild steel in simulated oil well water by an aqueous extract of Andrographis paniculata, Indian Journal of chemical Technology, 27, 452-460.

\title{
IZVOD
}

\section{INHIBICIJA KOROZIJE MEKOG ČELIKA U BUNARSKOJ VODI VODENIM EKSTRAKTOM SAPUNA (SAPINDUS TRIFOLIATUS)}

\begin{abstract}
Efikasnost inhibicije vodenog ekstrakta sapuna (Sapindus Trifoliatus) i $\mathrm{Zn}^{2+}$ u kontroli korozije mekog čelika u bunarskoj vodi na sobnoj temperaturi je procenjena primenom metode gubitka težine, studije polarizacije $i$ spektra impedanse naizmenične struje. Takođe, korišćeno je dinamičko rasejanje svetlosti i tvrdoća po Vikersu. Metoda gubitka težine otkriva da formulacija koja se sastoji od $10 \mathrm{ml}$ ekstrakta sapuna i $50 \mathrm{ppm} \mathrm{Zn}^{2+}$ ima $97 \%$ efikasnost inhibicije u kontroli korozije mekog čelika uronjenog u vodu iz bunara. Parametri sinergizma sugerišu da postoji sinergistički efekat između ekstrakta sapuna i $\mathrm{Zn}^{2+}$. Izoterma adsorpcije metalne površine je podređena Langmuir adsorpcionoj izotermi. Studija polarizacije otkriva da inhibitorni sistem funkcioniše kao anodni tip inhibitora. Spektri impedanse naizmenične struje potvrđuju zaštitni film formiran na površini metala. Studija dinamičkog rasejanja svetlosti (DLS) otkriva da je površina u nanometarskoj skali. Vikersova tvrdoća metalne površine je povećana u sistemu inhibitora.
\end{abstract}

Ključne reči: Sapindus Trifoliatus, inhibitor korozije, meki čelik, bunarska voda, dinamičko rasejanje svetlosti, tvrdoća po Vikersu.

\author{
Naučni rad \\ Rad primljen: 18. 07. 2021. \\ Rad korigovan: 24. 08. 2021. \\ Rad prihvaćen: 05. 09. 2021. \\ Rad je dostupan na sajtu: www.idk.org.rs/casopis
}

(C) 2021 Authors. Published by Engineering Society for Corrosion. This article is an open access article distributed under the terms and conditions of the Creative Commons Attribution 4.0 International license (https://creativecommons.org/licenses/by/4.0/) 